\title{
STUDY OF ABSORPTION AND DESORPTION OF BENALAXYL FROM NATURAL AND ACTIVATED BRARI AND DARDHA CLAY
}

\author{
Esad Behrami $^{1}$, Kledi Xhaxhiu ${ }^{1}$, Bedri Dragusha ${ }^{2 *}$, Arianit Reka ${ }^{3}$, Zehra Hajrulai-Musliu ${ }^{4}$, \\ Avni Berisha ${ }^{5}$, Adelaida Andoni ${ }^{1}$, Xhuljeta Hamiti ${ }^{1}$, Spiro Drushku ${ }^{1}$ \\ ${ }^{1}$ University of Tirana, Faculty of Natural Sciences, Department of Chemistry, Tirana, Albania; \\ ${ }^{2 *}$ University of Prishtina, Faculty of Agriculture and Veterinary, Department of Pomology and Viticulture, \\ Prishtina, Kosovo; \\ ${ }^{3}$ University of Tetovo, Faculty of Natural Sciences and Mathematics,Tetovo, Republic of North Macedonia; \\ ${ }^{4}$ Medicine Cyril and Methodius University in Skopje, Faculty of Veterinary, Republic of North Macedonia; \\ ${ }^{5}$ University of Prishtina, Faculty of Mathematics and Natural Sciences, Departament of Chemistry, \\ Prishtina, Kosovo;
}

"Correspondence Author Bedri Dragusha, e-mail: bedri.dragusha@uni-pr.ed; esat.behrami@uni-pr.edu;

Received March 2021; Accepted April 2021; Published June 2021;

DOI: https://doi.org/10.31407/ijees11.326

\begin{abstract}
The aim of this research was to study the adsorption progress of Benalaxyl from natural and activated clays of Brari and Dardha, so that these clays can be used for practical purposes fof soil and water purification. The natural clay materials originated from the regions of Brari (Tirana) $41^{\circ} 21^{\prime} 14.49^{\prime \prime} \mathrm{N} ; 19^{\circ} 50^{\prime} 17.74$.E and Dardha (Korça) $40^{\circ}$ $31^{\prime} 16.59$ " N; $20^{\circ} 49^{\prime} 33.69$ " E. SEM images of Dardha clay show a finer dispersity than Brari clay. Powder XRD analysis of reveal remarkable differences in their composition. Dardha clay shows a higher content of $\mathrm{SiO}_{2}, \mathrm{Al}_{2} \mathrm{O}_{3}$ and $\mathrm{CaO}$ than Brari clay. The adsorption dependence of Benalaxyl on Brari and Dardha clays was studied at $\mathrm{t}=$ $20^{\circ} \mathrm{C}$ and contact time: $12 \mathrm{~h} ; 24 \mathrm{~h} ; 48 \mathrm{~h} ; 72 \mathrm{~h}$, considering Benalaxyl concentrations of $0.1 \mathrm{~g} / \mathrm{l}$ and $0.3 \mathrm{~g} / \mathrm{l}$. Based on the time of contact clay-aqueous solution of benalaxyl, $48 \mathrm{~h}$ to $72 \mathrm{~h}$ showed significant adsorption of Benalaxyl onto clays, therefore this time interval is presented and oriented further studies in this time interval. Time intervals longer than $72 \mathrm{~h}$ showed no interest because the rate of hydrolysis increased. Most of Benalaxyl is desorbed from both clays within the first 2 hours. Dardha clay desorbs better than Brari clay.
\end{abstract}

Keywords: Benalaxyl, clay, brari, dardha, adsorption, desorption 